\title{
MRC-SPECT-DF: an MR-Compatible SPECT system with Dual-FOV collimation design for microscopic SPECT imaging
}

\author{
Xiaochun Lai', Chin-tu Chen², Ling-Jian Meng ${ }^{1 *}$ \\ From PSMR 2015: 4th Conference on PET/MR and SPECT/MR \\ La Biodola, Isola d'Elba, Italy. 17-21 May 2015
}

${ }^{1}$ University of Illinois, USA

We will report the design and performance of a MR-compatible SPECT system that utilizes a dual-FOV aperture design for microscopic SPECT imaging of small animals inside an pre-existing MR scanner. The MRC-SPECT-DF system consists of a full ring of high resolution CdTe detectors and an aperture that consists of dual-FOV aperture system design that has two sets of aperture rings along the axis, one providing a large FOV and the other one allowing an ultrahigh resolution microscopic imaging of a selected target region in the object. The switching between apertures does not require mechanical shifting of either the aperture or the CdTe detector ring. This is critical for integrating the SPECT system with the MR scanner, and minimizing the interference between both sub-system while operation.

Authors' details

${ }^{1}$ University of Illinois, USA. ${ }^{2}$ University of Chicago, USA.

Published: 18 May 2015

doi:10.1186/2197-7364-2-S1-A48

Cite this article as: Lai et al:: MRC-SPECT-DF: an MR-Compatible SPECT system with Dual-FOV collimation design for microscopic SPECT imaging. EJNMMI Physics 2015 2(Suppl 1):A48.

(c) 2015 Lai et al; licensee Springer. This is an Open Access article distributed under the terms of the Creative Commons Attribution License (http://creativecommons.org/licenses/by/4.0), which permits unrestricted use, distribution, and reproduction in any medium, provided the original work is properly cited.

Submit your manuscript to a SpringerOpen ${ }^{\bullet}$ journal and benefit from:

- Convenient online submission

- Rigorous peer review

- Immediate publication on acceptance

- Open access: articles freely available online

- High visibility within the field

- Retaining the copyright to your article

Submit your next manuscript at $\gg$ springeropen.com 